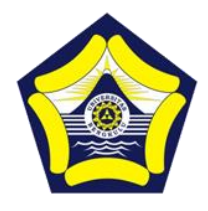

\title{
Evaluation of Supervisor Performance in the Implementation Aspect of Academic System in Elementary School
}

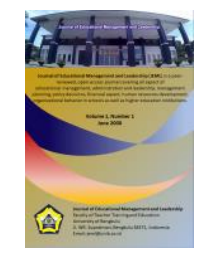

\author{
Sugimin $^{1 *}$ and Sumarsih ${ }^{2}$ \\ ${ }^{1}$ Sub-district Officer of Giri Mulya, Bengkulu \\ ${ }^{2}$ Program Studi S2 MAP, Universitas Bengkulu \\ *E-mail: sugimindiknas@gmail.com
}

DOI: https://doi.org/10.33369/jeml.1.1.11-13

\begin{abstract}
Performance appraisal is the process of evaluating how well employees do their work when compared to a set of standards, and also communicating with employees. Therefore, performance appraisal must be guided by the agreed upon standards in work standards. School supervisors are identical to the supervision of education which has a special meaning which is to help and participate in efforts to improve the quality of both personal and institutional. This study focused on the performance of supervisors in the aspects of implementing the academic system of teachers in public elementary schools throughout North Bengkulu. The method used was quantitative descriptive. The results of the supervisor's performance research in the aspects of implementing the academic system of teachers were in quite good category. Suggestions for supervisors should carry out all the main tasks of supervision properly including: preparing a program, implementing, evaluating the results of implementation, and reporting the evaluation results of program implementation.
\end{abstract}

Keywords: Supervisor performance, evaluation, teacher academic system.

\section{INTRODUCTION}

Performance appraisal is the process of evaluating how well employees do their work when compared to a set of standards, and also communicating with employees. Therefore, performance appraisal must be guided by the agreed upon standards in work standards. The main problem for evaluating performance is setting the criteria or standards (Timpe, 1988), (Mathis and Jackson, 1991).

To support the performance of the supervisory function at school, it is very important to pay a great attention. Related to supervision, Sagala (2010) defines "school supervisors are identical to the supervision of education which has a special meaning that is to help and participate in efforts to improve the quality of both personal and institutional".

In the above understanding, Sagala (2010) looks in detail at the supervisory function, which is to help the institutions and personnel who work at these institutions to carry out their duties in accordance with their vision and mission. To achieve that, of course, coaching and guidance are required so that personal quality is able to meet the desires of the institution. In relation to education, of course education personnel and others must have good quality and work professionally to achieve the visions, missions and goals of the educational institution. (Pecheone, \& Chung, 2006), (Nur, 2009)

Supervision by the supervisor needs to get the spotlight, because the problem of the performance of education supervisors has recently become a problem, as same as happened in the Public Elementary Schools in North Bengkulu Regency where the quality of education in primary schools has decreased. (Stiggins, \& Bridgeford, 1985), (Klimoski, \& Inks, 1990)

This research focused on primary school supervisors because it is the cornerstone of children's education. In the Law on the national education system it is emphasized that basic education is carried 
out with the aim of developing attitudes and abilities as well as providing the basic knowledge and skills needed to live in society and prepare students who meet the requirements to attend secondary education. This shows that through primary school education is started and to achieve quality human beings. In the future, elementary schools will be needed that will be able to provide a format for students that can be used to face the future. (Maryono,2016), (Syawal and Kartowagiran, 2013)

Based on this reason, the researchers wanted to know the performance of supervisors in the aspects of the implementation of the academic system of teachers in public elementary schools in North Bengkulu regency.

\section{RESEARCH METHOD}

Quantitative descriptive research in this study was to describe the symptoms and events that occur factually, systematically, and accurately.

This research was conducted in all elementary schools in North Bengkulu Regency covering 19 districts, namely Ketahun, Pinang Raya, Putri Hijau, Marga Sakti Sebelat, Napal Putih, Ulok Kupai, Arga Makmur, Arma Jaya, Air Besi, Enggano, Kerkap, Tanjungagung Palik, Hulu Palik, Air Napal, Lais, Batik Nau, Air Padang, Padang Jaya and Giri Mulya.

The population in this study was divided into 2, namely for managerial supervision and academic supervision. The data sources for evaluating the performance of supervisors in the academic field were elementary school teachers with a population of all teachers who are working in public elementary schools throughout North Bengkulu and determined as a sample of 100 teachers out of 2,244 teachers in state primary schools in North Bengkulu.

The population under managerial supervision was all 34 elementary school supervisors in North Bengkulu. The sample in this study was all members of the population, 34 people. In addition, the head of the service (1 person), the elementary school head ( 1 person), and the school principal. For the sample of school principals, it was determined as a sample of $20 \%$ (Arikunto, 2003) used the simple random sampling method. The number of principals used as samples were 46 principals. In order to obtain data from respondents, the researchers used structured questionnaire techniques as primary data, and interviews and documentation as secondary data.

\section{RESULTS AND DISCUSSION}

The teacher gave a score of 4 (the number of modes 4 ) of the statement given was 428 items, and the number of modes 3 was 1,071 items, the number of modes 2 was 266 items, and the number of modes 1 was 16 items. Meanwhile, there were 2 items that were not given a score (Mode 0). The maximum number of all modes was 1,781 items. If the data is presented in the form of diagram, the results of the academic assessment of the supervisor by the teacher are shown in the figure 1 . Based on the diagram, it was known that the most score data were 3 (often) with a percentage of $60 \%$.

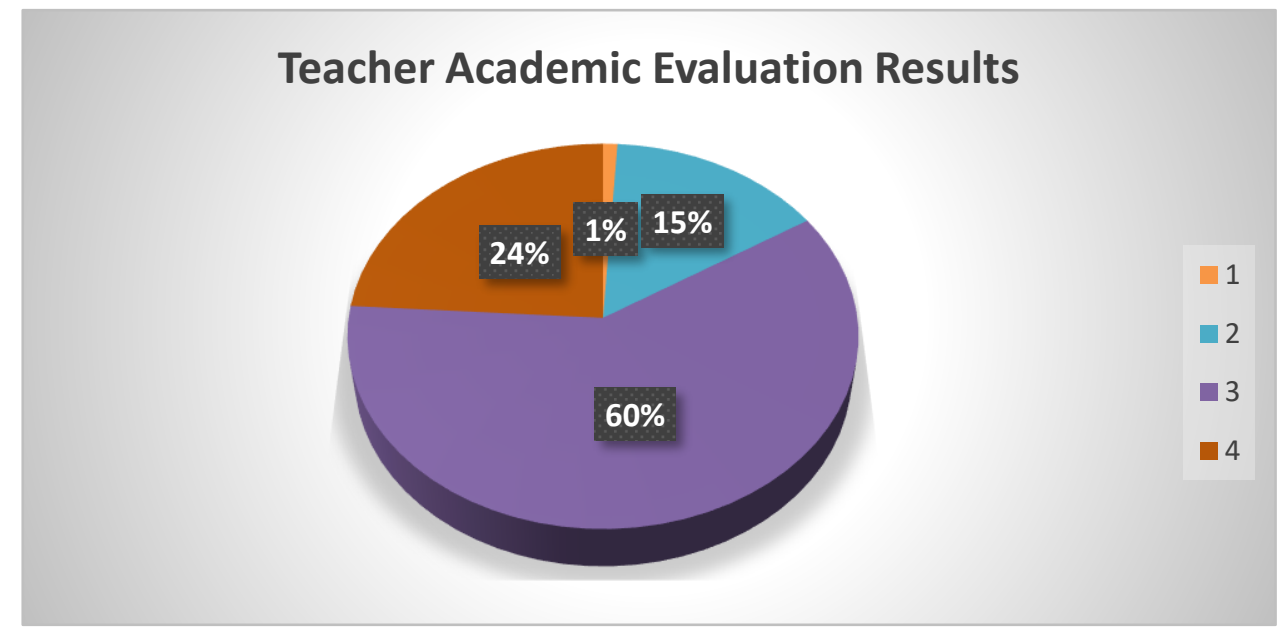

Figure 1. The diagram of teacher's academic evaluation results 


\section{CONCLUSIONS}

The general conclusions based on the results of the analysis that have been carried out are: the supervisor's performance in the aspects of the implementation of the teacher's academic system is in a good category. Based on the results of research, researchers provide input for supervisors to carry out all the main supervisory tasks properly including: preparing the programs, implementing, evaluating the results of implementation, and reporting the results of evaluations of program implementation.

\section{REFERENCES}

Arikunto, S. (2003). Metode Penelitian Administrasi. Jakarta: Rineka Cipta.

Dale, T. A. (1988). The Art and Science of Business Management Performance.

Klimoski, R., \& Inks, L. (1990). Accountability Forces in Performance Appraisal. Organizational Behavior and Human Decision Processes, 45(2), 194-208.

Maryono, M. M. (2016). Produktivitas Guru Bersertifikat Pendidik. Manajer Pendidikan, 10(4).

Mathis, R. L., \& Jackson, J. H. (1991). Personnel/Human Resource Management. Minneapolis, Mn: West Publishing Company.

Nur, H. (2009). Pendidik Dan Tenaga Kependidikan. Jurnal Medtek, 1(2), 1-10.

Pecheone, R. L., \& Chung, R. R. (2006). Evidence in Teacher Education: The Performance Assessment for California Teachers (Pact). Journal of Teacher Education, 57(1), 22-36.

Sagala, S. (2010). Supervisi Pembelajaran Dalam Profesi Pendidikan. Bandung: Alfabeta.

Stiggins, R. J., \& Bridgeford, N. J. (1985). Performance Assessment for Teacher Development. Educational Evaluation and Policy Analysis, 7(1), 85-97.

Syawal, J., \& Kartowagiran, B. (2013). Evaluasi Kinerja Pengawas Sekolah Dalam Melakukan Supervisi Penyelenggaraan Pendidikan SD Di Kota Tidore Kepulauan. Jurnal Evaluasi Pendidikan, 1(2), 208-222. 